\title{
Itan: entre o mito e a lenda
}

Daniela Barreto de Souza ${ }^{1}$ Adílio Junior de Souza ${ }^{2}$ http://lattes.cnpq.br/4840841008203387

Enviado em: 09/09/2018

Aceito em: 22/03/2019

Resumo: Este artigo discute o conceito de mito e lenda, com ênfase no estudo do Itan. Para isso, é feita uma revisão de literatura sobre o tema. A base teórica é formada por Araújo (1993), Arinos (1993), Barbosa Jr. (2011), Eliade (1972), Fontes (2013), Póvoas (2004), Vansina (2016), Verger (1997) e outros. O estudo tem como objetivos: compreender o que são mitos e lendas, analisar diferentes tipos de mitos/lendas através de narrativas orais, refletir sobre o Itan, criticamente. A metodologia adotada é a pesquisa exploratória, com uso de narrativas/entrevistas. Os resultados sinalizam que o Itan possui relação com o mito e a lenda, porquanto são determinados pela crença/descrença dos indivíduos.

Palavras-Chave: Itan; mito; lenda; narrativa oral.

Abstract: This paper discusses the concept of myth and legend, with emphases in the study of Itan. For this, is done a literature review. The theoretical base is formed by: Araújo (1993), Arinos (1993), Barbosa Jr. (2011), Eliade (1972), Fontes (2013), Póvoas (2004), Vansina (2016), Verger (1997), and others. The study has as objectives: comprehending what are myths and legends, analyse different kinds of myths/legends though oral narratives, reflecting about Itan, critically. The methodology adopted is an exploratory research with the use of narratives/interviews. The results signalize that the Itan has relation with myth and legend, because they are determined by belief/disbelief of the individuals.

Keywords: Itan; myth; legend; oral narrative.

\section{INTRODUÇÃO}

O Candomblé através dos Orixás é um dos mais antigos cultos religiosos da humanidade. Desse culto originaram-se narrativas de inestimável valor literário, artístico e religioso, o Itan, que merece ser conhecido, respeitado e prestigiado mesmo por quem não é adepto da religião.

Um dos motivos do desconhecimento do Itan é o fato dele estar ligado a uma religião originada na África, disseminada pelos negros que foram escravizados. Parte da população brasileira ainda é preconceituosa e sem conhecimento sobre a cultura africana, fazendo-se necessárias pesquisas e estudos para se familiarizar com o conteúdo, pois o mesmo se tornou obrigatório no ensino da História e Cultura africana e afro-brasileira nas instituições de ensino básico, de acordo com a Lei 10.639, que entrou em vigor no ano de 2003.

O Itan é o conjunto de mitos e lendas do panteão africano. Pode-se constatar que a palavra

\footnotetext{
${ }^{1}$ Graduada em Letras e pós-graduanda em Língua portuguesa e Literatura Brasileira e Africana de Língua Portuguesa pela Universidade Regional do Cariri (URCA), graduanda em Administração Pública pela Universidade Estadual do Ceará (UECE). E-mail: danybarreto1@hotmail.com

2 Mestre e doutorando em Linguística Pela Universidade Federal da Paraíba, professor temporário de língua latina da Universidade Regional do Cariri, campus de Campos Sales - CE. E-mail: adilivs@gmail.com
} 
Itan, com exceção dos participantes do Candomblé, é desconhecida, mesmo sendo um país onde a influência africana faz parte de seu processo de construção de uma identidade cultural.

A principal meta deste artigo é refletir criticamente sobre a noção do que seja um Itan, tendo em vista a compreensão não apenas do termo em si, mas também no que diz respeito ao que ele representa para o Candomblé enquanto elemento representativo de uma cultura oral.

Tratando-se, portanto, de analisar a origem do Itan, partindo da premissa de ser este um elemento da oralidade. Além disso, o estudo ainda se propõe a refletir sobre os Orixás do Candomblé, bem como distinguir a noção de mito e lenda.

Neste artigo, defende-se a importância da literatura africana dos orixás, seu valor enquanto patrimônio cultural e religioso do Brasil. Ressalta-se também que aceitação ao diferente, a outras religiões ou crenças é muito mais que uma mera atitude, deve ser, antes de qualquer coisa, um ato de respeito desprovido de qualquer tipo de preconceito.

\section{MATERIAIS E MÉTODOS}

O instrumental teórico-metodológico utilizado nesse trabalho foi a pesquisa exploratória na qual se fez um levantamento bibliográfico, entrevistas com pessoas que têm experiências práticas com o Itan. Através dessas entrevistas foram analisados os exemplos que estimularam a compreensão de que o Itan é repassado através da oralidade, sendo uma forma básica de atividade linguística.

As entrevistas foram feitas no Ilê Omo Osún (Casa de Oxum) com o intuito de que o ambiente destinado aos orixás se torne mais inspirador para os colaboradores, pois se trata de narrar o sagrado. Referenciando o Itan recitado no tempo de Candomblé Ilê Omo Osún conhecido como Casa de Oxum, localizado no Distrito Barra, do município de Aiuaba, no Estado do Ceará. É um terreiro fundado em 8 de dezembro de 2007, pelo Babalorixá André Henrique Freitas (André de Oxum), trinta pessoas fazem parte da casa que desenvolvem atividades religiosas.

Ao longo de sua história, contribui de modo significativo para preservar e difundir a cultura africana na região. Comprometida na luta contra o preconceito e a intolerância religiosa, realiza ações que visam a valorizar o legado cultural afro-brasileiro e garantir o direito de cada cidadão em professar livremente sua fé.

Não foram feitas perguntas destinadas à opinião ou a outras questões dos colaboradores, permitindo que eles tivessem mais liberdade para relatar o Itan de sua preferência. Os colaboradores pertencem ao Ilê Omo Osún, levando-se em conta o tempo que se tem de iniciação no Candomblé e consequentemente a experiência que eles têm em narrar o Itan.

O registro dos depoimentos dos narradores foi através da escrita, onde não se levou em conta exatamente as falas originais dos informantes, com seus aspectos fonéticos e morfossintáticos distintos, mas apenas aproximações dos seus modos originais de fala, no intuito de facilitar a leitura. Para a segurança dos colaboradores, optou-se por atribuir-lhes nomes fictícios, tais como: José, Maria, Pedro e uma atribuição da divindade narrada, etc.

A análise do Itan dos colaboradores destaca a importância e o valor da tradição oral (por serem narradas) e da tradição escrita (por desta forma serem registradas neste artigo).

A partir da análise interpretativa dos aspectos tipológicos de gênero textual que o Itan representa (a narrativa), sendo apresentada de forma mais ampla, pois podem ser analisadas a partir das situações sociais em que são usados. Evidencia-se que o Itan possui diferentes 
maneiras de organizar as informações linguísticas sendo que por muitas vezes confundem se eles são classificados como mitos ou como lendas do panteão africano.

A relevância social trazida pelo Itan está no arquétipo de cada orixá, que traduzem condutas sociais orientados para a preservação ambiental, a explicação ou histórias que fundamentam a origem da Terra, dos elementos da natureza e respeito às diversidades e o requerimento de justiça.

As lendas e mitos constituem como relevância social uma ferramenta fundamental para conhecer e investigar as distintas culturas, que nos permite conhecer saberes coletivos ancestrais que representam a diversidade dos povos que dão origem a cada uma delas.

\section{A TRADIÇÃO ORAL E ESCRITA}

O ser humano iniciou a transmissão do conhecimento através da tradição oral na qual aprender e repassar o conhecimento através da oralidade faz parte de um processo de aprendizagem onde as pessoas daquelas sociedades são submetidas. Marcuschi aponta que, a oralidade como prática social se desenvolve naturalmente em contextos informais do dia-a-dia (MARCUSCHI, 2007).

A oralidade dá origem à literatura de tradição oral, pois é através dela que o homem armazena e transmite o conhecimento, fazendo uso da memória e da fala. Segundo Vansina (2016) toda e qualquer sociedade oral aceita que a fala é muito mais que a mera comunicação, é também o meio pelo qual se pode preservar toda a sapiência de antigos ancestrais daquele povo, ou seja, é através da oralidade que se conserva uma determinada tradição. Esta tradição oral pode ser definida, de fato, como um testemunho transmitido verbalmente de uma geração para outra.

A tradição oral faz o uso da memória auditiva e visual que no princípio das civilizações eram os únicos recursos de que dispunham as culturas orais para o armazenamento e a transmissão do conhecimento às futuras gerações foi assim que as civilizações africanas puderam repassar até hoje sua influência na estrutura do pensamento e da cultura de sociedades letradas.

É notório que através do discurso narrativo em uma sociedade oral, muitas obras literárias provêm desse ato de narrar histórias independentemente do gênero em que ela esteja inserida, a oralidade é como uma base para a literatura, pois antes de ser escrita ela deve ser pensada e muitas vezes narrada.

Toda literatura oral tem sua própria divisão em gêneros literários. O historiador não só tentará apreender o significado desses gêneros para a cultura que está estudando, mas também colherá ao menos uma amostra representativa de cada um, pois em todos eles podem-se esperar encontrar informações históricas, além do que, as tradições que o interessam particularmente são mais fáceis de se compreender quando analisadas no contexto geral. Já a própria classificação interna fornece indicações valiosas. Assim, podemos descobrir se os transmissores de uma obra literária fazem distinção, por exemplo, entre as narrativas históricas e as de outros tipos. Os gêneros literários também estão sujeitos a convenções literárias, cujo conhecimento é fundamental para se compreender o verdadeiro sentido da obra (VANSINA, 2016. [s/p]).

A tradição oral e a escrita possuem grande relação, porém as duas se divergem nos seguintes aspectos. Um documento escrito é um objeto: um manuscrito. Mas um documento oral pode ser definido de diversas maneiras, pois um indivíduo pode interromper seu testemunho, corrigir-se, recomeçar, etc. (VANSINA, 2016).

https://periodicos.unifap.br/index.php/letras

Macapá, v. 8, n. 3, $2^{\circ}$ sem., 2018 
A tradição escrita surgiu ao longo das práticas comunicativas, esta e a tradição oral são duas maneiras de textualizar e produzir discursos. Primeiro surgiu a oralidade e logo depois se sentiu a necessidade de registrar aquilo que era dito, a escrita de certo modo depende da oralidade e ao mesmo tempo a preserva através do registro dos discursos com originalidade. $\mathrm{O}$ fato de a escrita registrar-se como documento presume que sua permanência seja concretizada com mais eficácia em relação à oralidade.

Procurando definir a relação entre escrita e oralidade, Marcuschi (2007, p. 36), afirma que:

Há autores que consideram a tradição da escrita como veículo por excelência da cultura, do pensamento e do raciocínio abstrato, ao passo que a tradição oral seria mais concreta e apta para o saber intuitivo e prático ou para a transmissão da experiência cotidiana.

No entanto, não se pode apontar a escrita como apenas uma transcrição da fala levando em consideração que não se escreve como se fala. A escrita possui regras, mas ao mesmo tempo representa a oralidade que é mais presente no nosso dia-a-dia. A contestação entre ambas está no processo da produção textual perante as modalidades de uso da língua, pois é no uso que a língua se concretiza, tanto na fala, quanto na escrita.

\section{O CANDOMBLÉ ATRAVÉS DOS ORIXÁS COMO PRECURSOR DO ITAN}

A palavra Itan é uma palavra de modo invariável mesmo quando for referida no plural. O Itan é o conjunto de mitos e lendas do panteão africano que narra as histórias envolvendo canções, danças, rituais e ensinamentos. Para os Yorubás é considerado como verdade absoluta sobre a criação do mundo, possuindo grande respeito por ter sido repassado oralmente como ensinamentos através dos mais velhos.

Este assunto tem sido profundamente discutido por inúmeros autores, entre os quais vale ressaltar: Araújo (1993), Arinos (1993), Barbosa Jr. (2011), Eliade (1972), Fontes (2013), Póvoas (2004), Vansina (2016) e Verger (1997), entre muitos outros. Nestes e noutros estudos, o mito e a lendo são discutidos a partir de variados enfoques teóricos.

O homem sempre buscou explicação para tudo na natureza, dando a certos fenômenos naturais um ar sobrenatural. No Candomblé a reverência aos elementos da natureza, corporificados nos orixás, constitui a essência da sua experiência religiosa, pois são representantes dos elementos: do fogo, da água, da terra e do ar.

O culto aos Orixás reverencia além da natureza outra riquíssima fonte de sabedoria e cultura: a família. O Candomblé é a religião do acolhimento, da vida em família, da ancestralidade que busca a união entre os planos sagrado e humano. De acordo com Verger (1997, p. 9), que assim esclarece:

A religião dos orixás está ligada à noção de família. A familia numerosa, originária de um mesmo antepassado, que engloba os vivos e os mortos. O orixá seria, em princípio, um ancestral divinizado, que, em vida, estabelecera vínculos que the garantiam um controle sobre certas forças da natureza, como o trovão, o vento, as águas doces ou salgadas, ou, então, assegurando-lhe a possibilidade de exercer certas atividades como a caça, o trabalho com metais ou, ainda, adquirindo o conhecimento das propriedades das plantas e de sua utilização o poder, àsé do ancestral-orixá teria, após a sua morte, a faculdade de encarnar-se momentaneamente em um de seus descendentes durante um fenômeno de possessão por ele provocada.

https://periodicos.unifap.br/index.php/letras Macapá, v. 8, n. 3, $2^{\circ}$ sem., 2018 
Nos rituais são feitos o uso de máscaras, esculturas, adornos diversos, pintura corporal, sacrifícios, entre outros. As danças realizadas nos rituais não são simples coreografias, é praticamente uma linguagem das mais eficazes para travar diálogos entre os deuses, os adeptos e a natureza. Essas divindades da natureza, por meio dos rituais ficam mais próximas de nós e através do Itan, nos educam e nos ensinam a conhecer nossas potencialidades e defeitos.

A oralidade é a maior especialidade do Candomblé, pois a transmissão do conhecimento e valores é repassada de forma oral dos mais velhos aos mais novos.

Vale ressaltar que ITAN é uma palavra iorubá que significa história, qualquer história; um conto. De um modo mais específico, itan são histórias do sistema nagô de consultas às divindades. Na África, os itan compunham, e ainda compõem, o oráculo denominado de Ifá, que pode ser lido e interpretado através de um conjunto de dezesseis sinais, os odu. Esses sinais podem se combinar entre si, resultando em 256 outros sinais, que também se combinam entre si, perfazendo um total de mais de quatro mil sinais. Esses sinais são explicados através de várias histórias que compõem cada um deles. O sacerdote, o babalaô, sabe essas histórias de cor, pois o sistema era baseado apenas na comunicação oral (PÓVOAS, 2004, p. 25).

Cada orixá possui uma função social que é repassada através do Itan podendo ser divididas através dos quatro elementos da natureza no qual cada um responde: fogo, terra, água e $a r$.

\subsection{Divindade do fogo}

Exú está ligado a todas as energias do universo. É o mensageiro de todos os orixás, por isso deve ser o primeiro orixá a ser agradado antes de qualquer outro, ele é quem faz a ligação entre o mundo dos orixás e o mundo humano. Também é chamado de Elegbará, o Senhor da Vida. É ligado ao sexo, fertilidade e aos prazeres. De acordo com Verger (1997, p.39):

Exu é um orixá de múltiplos e contraditórios aspectos, o que torna difícil defini-lo de maneira coerente. De caráter irascível, ele gosta de suscitar dissensões e disputas, de provocar acidentes e calamidades públicas e privadas. É astucioso, grosseiro, vaidoso, indecente, a tal ponto que os primeiros missionários, assustados com essas características, compram-no ao diabo, dele fazendo o símbolo de tudo o que é maldade, perversidade, abjeção, ódio, em oposição à bondade, à pureza, à elevação e ao amor de Deus. Entretanto, exu possui o seu lado bom e, se ele é tratado com consideração, reage favoravelmente, mostrando-se serviçal e prestativo.

Exú é confundido com o Diabo, figura do Cristianismo, porém os dois não possuem nenhuma relação, até porque para os candomblecistas não existe o Diabo. E por ser uma divindade ligada ao transporte ele é um intermediário entre os outros orixás, também conhecido como o dono das encruzilhadas. Assim, acredita-se que Exú é: "Responsável pelo transporte das oferendas aos outros orixás e também pela comunicação com eles é, portanto, seu intermediário. Como reza antigo provérbio, 'Sem Exú não se faz nada" (BARBOSA JR., 2011, p. 33).

Exú é respeitado por todos, pois é ele quem leva as oferendas às demais divindades, então primeiramente ele é quem deve ser agradado.

Ogum é irmão de Exú e Xangô e filho de Yemanjá. A guerra, a agricultura e a tecnologia 
são seus domínios, pois ele é o grande orixá ferreiro que deu origem as ferramentas para poder cultivar a terra, assim como criou as armas para guerrear.

Ogum é o deus do ferro, dos ferreiros e de todos aqueles que utilizam esse material: agricultores, caçadores, açougueiros, barbeiros, marceneiros, carpinteiros, escultores. Desde o início do século, os mecânicos, os condutores de automóveis ou de trens, os reparadores de velocípedes e de máquinas de costura vieram juntar-se ao grupo de seus fiéis (VERGER, 1997, p. 45).

Ogum simboliza a capacidade de criação do homem, pois ele forjou todo instrumento que se tenha como matéria-prima o ferro. Assim, Ogum:

É o orixá do sangue que sustenta o corpo, da espada, da forja e do ferro, é o padroeiro daqueles que manejam ferramentas. Patrono dos conhecimentos práticos e da tecnologia simboliza a ação criadora do homem sobre a natureza, a inovação, a abertura de caminhos em geral (BARBOSA JR., 2011, p. 35).

Xangô é o orixá que possui exacerbado senso de justiça. Também é considerado o Orixá do fogo, poderoso, autoritário e inspira respeito por onde passa. Extremamente sensual, ele teve três esposas: Iansã, Oxum e Obá. Xangô possui as seguintes qualidades:

Xangô é viril e atrevido, violento e justiceiro; castiga os mentirosos, os ladrões e os malfeitosos. Por esse motivo, a morte pelo raio é considerada infamante. Da mesma forma uma casa atingida pelo raio é uma casa marcada pela cólera de Xangô (VERGER, 1997, p. 93).

Xangô representa a justiça através de seus dois machados, estes machados também reproduzem o som dos trovões. Suas decisões são sempre tomadas como certas ele é quem decide o que é o bem e o mal.

Sendo senhor cortês e poderoso, demonstra temperamento voluntarioso e energético, irritando-se à menor contradição de suas ordens, sujeito a crises incontroláveis de ira. Consciente de sua abnegação possui elevado sentido de dignidade e cumprimento das obrigações assumidas, demonstrando sempre profundo senso de respeito e justiça (ARAÚJO, 1993. p. 61).

O fogo foi e é muito importante para a evolução humana, por isso no Candomblé ele é objeto de culto, sendo um misto de bem e mal. Apesar de ser o elemento que queima e consome, também é símbolo de purificação.

\subsection{Divindades da terra}

Oxóssi é o orixá da caça e da fartura de alimentos, a nação Kêto o reverencia como rei, a ele é pedido que nunca haja necessidades ou fome. Desta maneira Verger (1997, p. 56) caracteriza Oxóssi:

Oxóssi, o deus dos caçadores, teria sido o irmão caçula ou filho de Ogum. Sua importância deve-se a diversos fatores. O primeiro é de ordem material, pois, como Ogum, ele protege os caçadores, torna suas expedições eficazes, delas resultando caça abundante. O segundo é de ordem médica, pois os caçadores passam grande parte do seu tempo na floresta, estando em contato freuente com Ossain, divindade das folhas terapêuticas e litúrgicas, e aprendem com ele parte do seu saber. O terceiro é de ordem social, pois normalmente é um caçador que, durante suas expedições, descobre um lugar favorável à instalação de uma nova roça ou de um

https://periodicos.unifap.br/index.php/letras

Macapá, v. 8, n. 3, $2^{\circ}$ sem., 2018 
vilarejo. Torna-se assim o primeiro ocupante do lugar e senhor da terra (Oníle), com autoridade sobre os habitantes que aí venham a se instalar posteriormente. O quarto é de ordem administrativa e policial, pois antigamente os caçadores eram únicos a possuir armas no vilarejo, servindo também de guardas-noturnos.

Oxóssi tem o intuito de incentivar o equilíbrio ecológico, apesar se ser caçador, os ensinamentos que são aprendidos no Itan dele não incentiva a caça desequilibrada, tendo somente o objetivo de alimentação, também é ligado às vegetações. Dito de outra maneira, sobre Oxóssi se pode afirmar:

Ligado à floresta, à árvore, aos antepassados, Oxóssi como caçador ensina o equilíbrio ecológico, e não o aspecto predatório da relação do homem com a natureza. Com ele, aprendemos a concentração, a determinação e a paciência necessária para a vida ao ar livre (BARBOSA JR., 2011, p. 37).

Oxóssi é pai de Logun Edé um orixá jovem, que herdou muito do pai na habilidade de caçar, mas assim como sua mãe Oxum também tem domínio sobre as águas doces de rios e cachoeiras.

Esse deus tem por particularidade viver seis meses do ano sobre a terra, comendo caça, e os outros seis meses, sob as águas de um rio, comendo peixe. Ele seria também, alternadamente do sexo masculino, durante seis meses, e do sexo feminino durante os outros seis meses. (VERGER, 1997, p.55).

Logun Edé tem traços infantis vive na companhia de sua amiga Ewá, os dois são orixás que não atingiram a fase adulta, permanecendo adolescentes, Logun é solidário gosta de ajudar, possui ar de mistério e encanto. Muitos entendem este orixá como:

Príncipe dos orixás combina a astúcia dos caçadores com a paciência dos pescadores. Seus pontos de força, na natureza, compreendem barrancas, beira de rios, o vapor fino sobre as lagoas, que se espraia pela mata nos dias quentes. Vivencia plenamente os dois reinos, o das águas e o das matas (BARBOSA JR., 2011, p. 39).

Obaluayê carrega consigo todas as doenças desde que nasceu; ele mesmo é doente, porém não se pede a ele que traga saúde, pois o mesmo não a tem, o que se pede é que livrem a todos das doenças. Ele também é conhecido por outros nomes, os quais não são pronunciados com frequências por serem remetidos à doenças:

Obalúayé ('Rei Dono da Terra') ou Omolu ('Filho do Senhor') são os nomes geralmente dados a Sànpònná, deus da varíola e das doenças contagiosas, cujo nome é perigoso ser pronunciado. Melhor definindo, ele é aquele que pune os malfeitores e insolentes enviando-lhes a varíola (VERGER, 1997, p.80).

Esse orixá é muito respeitado, seu Itan conta que o rosto de Obaluayê era coberto de chagas repulsivas por esse motivo é coberto por palhas da costa. Desta maneira acreditase que Obaluayê é: "o orixá responsável pelas passagens, de plano para plano, de dimensão para dimensão, da carne para o espírito, do espírito para a carne. Relaciona-se com a saúde e a doença possuindo estreita ligação com a morte" (BARBOSA JR., 2011, p.46).

Ossain é dono dos segredos da natureza, patrono da farmácia, dos sacerdotes, químicos que usam plantas para fins curativos e, ou ritualísticos. A partir do poder de suas ervas são 
feitos remédios para curar as doenças.

Ossain é a divindade das plantas medicinais e litúrgicas. A sua importância é fundamental, pois nenhuma cerimônia pode ser feita sem a sua presença, sendo ele o detentor do àsé (o poder), imprescindível até mesmo aos próprios deuses. O nome das plantas, a sua utilização e as palavras (ofo), cuja força desperta seus poderes, são os elementos mais secretos do ritual no culto aos deuses iorubás (VERGER, 1997, p. 56).

As ervas são sagradas no culto aos orixás, delas são feitos os banhos sagrados do Candomblé e por isso sempre se reverencia Ossain, é a representação do homem com o verde da natureza é o senhor dos segredos medicinais, também atua com ágil protetor das matas.

Esses orixás que representam a terra simbolizam a fertilidade dos vegetais, espiritualmente falando é a firmeza para enfrentar a vida e continuar a caminhar.

\subsection{Divindades das águas e da fertilidade}

Yemanjá é o orixá mais popular no Brasil, conhecida como a rainha dos oceanos é a mãe de todos, muito reverenciada pelo extinto materno teve quatro filhos orixás (Exú, Ogum, Oxóssi e Xangô) sendo que ainda criou os filhos rejeitados de Nanã (Oxumaré e Omolu). Pode ser conhecida por vários outros nomes e também por ser a maior referência de maternidade no mundo dos orixás: "Iemanjá tem diversos nomes, como no caso de Oxum, aos diferentes lugares profundos (ibù) do rio. Ela é representada nas imagens com o aspecto de uma matrona, de seios volumosos, símbolo de maternidade fecunda e nutritiva" (VERGER, 1997, p. 74).

Yemanjá representa os oceanos e a vida marinha de forma geral, assim como as ondas pode ser calma ou nervosa. É maternal e protetora, é conhecida por ser a mãe de todos.

Oxúm é o orixá que se atribui o útero e todo o sistema reprodutor feminino, é vaidosa, gosta de ouro e jóias. É a senhora Iaodê, dona das águas doces.

Oxum é chamada de İyálóòde (Iaodê) título conferido à pessoa que ocupa o lugar mais importante entre todas as mulheres da cidade. Além disso, ela é a rainha de todos os rios e exerce seu poder sobre a água doce, sem a qual a vida na terra seria impossível (VERGER, 1997, p. 67).

Oxum também é lembrada por representar o amor, a sensualidade e a beleza feminina, sua aparamenta preferida é o espelho, que usa pra se admirar. Desse modo, “Oxum é senhora dos regatos, e das fontes de água clara, deusa do dengo e da formosura, vaidosa e coquete. Seu ritmo chamado Ijexá, região da África banhada pelo rio Oxum, é lento, voluptuoso e sensual" (ARAÚJO, 1993. p. 91).

Obá é guerreira e muito forte, não é feminina e é consciente de seu poder, enfrenta e derruba qualquer um que vier enfrentá-la.

Obá, divindade do rio de mesmo nome, foi a terceira mulher de Xangô. Como as duas primeiras, Oiá e Oxum, ela foi também mulher de Ogum segundo uma lenda de Ifá: Obá era um orixá feminino muito enérgico e fisicamente mais forte que muitos orixás masculinos. Ela desafiara e vencera na luta, sucessivamente, Oxalá, Xangô e Orunmilá. Chegada à vez de Ogum, aconselhado por um babalaô, ele preparou uma oferenda de espigas de milho e quiabo. Amassado tudo num pilão, obtendo uma pasta escorregadia, que espalhou pelo chão, no lugar onde aconteceria a luta. Chegado o momento, Obá, que fora atraída até o lugar previsto, escorregou sobre a mistura, aproveitando-se Ogum para derrubá-la e possuí-la no ato (VERGER, 1997, p. 71).

https://periodicos.unifap.br/index.php/letras

Macapá, v. 8, n. 3, $2^{\circ}$ sem., 2018 
Yewá é o orixá do rio que na África corre paralelo ao rio Ògùn, é irmã gêmea de Oxumaré herdando de seu irmão as características e poderes de serpente. Yewá domina a vidência, sendo dona do mundo e dos horizontes é protetora das virgens e de tudo o que é inexplorável. É um orixá muito misterioso e seus filhos são raros e de beleza exótica. Barbosa (2011, p.51) define Ewá como protetora das virgens e a relaciona com os seguintes elementos da natureza:

Protetora das virgens, tem o poder de vidência, sendo senhora do céu estrelado. Além do arpão seu símbolo mais conhecido, pode também carregar um Ofá (arco e flecha) dourado, uma espingarda ou uma serpente de metal. Também simbolizada pelo raio de sol, pela neve e pelas palmeiras em formato de leque.

Oxumaré está diretamente ligado às riquezas e a fortuna, possui os dois sexos sendo hermafrodita e é manifestado através do arco-íris ligando o céu e a terra. Sendo relatado também da seguinte maneira:

Oxumaré é a serpente-arco-íris; suas funções são múltiplas. Oxumaré é a mobilidade e a atividade. Uma de suas obrigações é a de dirigir as forças que produzem o movimento. Ele é o símbolo da continuidade e da permanência e, algumas vezes, é representado por uma serpente que se enrosca e morde a própria cauda. Enrola-se em volta da terra para impedi-la de se desagregar. Se perdesse as forças, isso seria o fim do mundo... Eis aí uma excelente razão para não se negligenciar as suas oferendas (VERGER, 1997, p.78).

Oxumaré representa a riqueza não só material, mas também espiritual, ele estanca a chuva, é ligado a fecundidade e a continuação da vida, é o ciclo constante representado pela cobra que morde a própria cauda. Ele ajudou na criação do mundo e controla os movimentos:

Oxumaré participou da criação do mundo, enrolando-se ao redor da Terra, reunindo toda a matéria para, enfim dar uma forma ao mundo. Desenhou vales e rios, rastejando mundo afora. Responsável pela sustentação do mundo, controla os movimentos dos astros e oceanos (BARBOSA JR., 2011, p. 48).

Nanã sintetiza em si a morte, fecundidade e riqueza. É uma divindade idosa, representa a ancestralidade e o respeito aos mais velhos. Verger (1997, p. 90) a considera:

A mais antiga das divindades das águas, não das ondas turbulentas do mar, como Iemanjá, ou das águas calmas dos rios, domínio de Oxum, mas das Águas paradas dos lagos e lamacentas dos pântanos. Estas lembram as águas primordiais que Odùduà ou Òrànmíyàn (segundo a tradição de Ifé ou e Oyó) encontrou no mundo quando criou a terra.

É marcada pela personalidade taciturna e impertinente, porém por ter experiência é muito paciente com crianças por ser uma boa avó, evidenciando serenidade e carinho.

Senhora da vida (lama primordial) e da morte (dissolução do corpo físico na terra), seu símbolo é o ibiri, feixe de ramo de folha de palmeiras, com a ponta curvada e enfeitado com búzios. Nanã rege a maturidade, bem como atua no lado racional dos seres (BARBOSA JR., 2011, p.44).

As divindades ligadas ao elemento água sempre estão relacionadas à criação do mundo 
e a fertilidade, sendo a maioria do sexo feminino, com exceção de Oxumaré que possui os dois sexos, no Candomblé a água é a grande mãe criadora da vida e da continuação da mesma.

\subsection{Divindades do ar}

Oyá é uma divindade das nuvens pesadas e tornados, mas também é relacionada ao elemento ar, as tempestades e aos raios, visto que:

Oya (Oiá) é a divindade dos ventos, das tempestades e do rio Níger que, em iorubá, chama-se Odòya. Foi a primeira mulher de Xangô e tinha um temperamento ardente e impetuoso. Conta uma lenda que Xangô enviou-a em missão na terra dos baribas, a fim de buscar um preparado que, uma vez ingerido, lhe permitiria lançar fogo e chamas pela boca e pelo nariz. Oiá, desobedecendo às instruções do esposo, experimentou esse preparado, tornando-se também capaz de cuspir fogo, para grande desgosto de Xangô, que desejava guardar só para si esse terrível poder (VERGER, 1997, p. 64).

Oxalá é paciente, calmo, tranquilo assume duas formas: oxaguiã jovem guerreiro, e oxalufã, velho apoiado num bastão de prata (apaxoró). Na África, todos os Orixás relacionados com a criação são designados pelo nome genérico de Orixá Fun Fun.

Òrìsànlá ou Obàtálá, 'O Grande Orixá' ou 'Rei do Pano Branco', ocupa uma posição única e inconteste do mais importante orixá e o mais elevado dos deuses iorubás. Foi o primeiro a ser criado por Olodumaré, o deus supremo (VERGER, 1997, p.100).

Oxalá é sábio e como foi o primeiro orixá que iniciou a criação do mundo todos o respeitam muito, em toda sexta-feira da semana evita-se comer carne, sexo, bebidas e vestese de branco para homenagear o pai criador, portanto: “É o orixá maior, responsável pela criação do mundo e do homem. Pai de todos os demais orixás, Oxalá (Orinxalá ou Obatalá) foi quem deu ao homem o livre-arbítrio para trilhar seu próprio caminho" (BARBOSA JR., 2011, p.67).

Os orixás são personagens do Itan que através das narrativas orais resultam como produto arcaico da cultura Africana. Essas narrativas servem, dentre outras funções básicas, para acumulação, armazenamento e transmissão de conhecimentos.

De acordo com Póvoas (2004, p.13), a consistência do Itan, a pluralidade dos seus sentidos, é que dá a sua perenidade e, depois, é o que permanece na alma do povo: o sentido. E por isso, porque eles encerram sentido, visto que permanecem na memória e são passados de geração a geração.

\section{LENDAS E MITOS}

Através das narrativas orais e escritas o homem pôde transpor o imaginário e demonstrar seus sentimentos que a razão não pode explicar fazendo-os assim com que eles sejam mistificados. Essas narrativas são classificadas por uns como lendas e por outros como mitos. Mas afinal o que são lendas e mitos?

O mito tenta contar a história de criação do mundo envolvendo os elementos da natureza e os cosmos, existem dois tipos de mitos: os mitos cosmogônicos e os mitos de origem. Eles têm o objetivo de responder as incógnitas entre o homem e o universo, com base 
nessas ideologias o mito caracterizou-se com uma relevância sobre o sagrado, sintetizando o bem e o mal, o certo e o errado em caráter religioso.

A narrativa que marca o mito é cercada das proezas dos seres sobrenaturais e do mistério, desse modo dá sentido à cultura. Uma dúvida comum entre muitas pessoas é sobre a veracidade ou não do mito, sabe-se que este está agregado a religiosidade e a moralidade, respeitar esse mito e crer nele como um fato verídico é algo que depende da cultura em que se é inserido.

Antes o mito era visto como verdade absoluta, mas a seguir pode-se notar que seu sentido mudou e atualmente é visto como fato inverídico, assim afirma Fontes (2013, p. 9):

Originalmente, um mito era entendido como uma verdade absoluta, merecedor de crença profunda e até veneração. Serviam como explicações da origem do homem, do mundo e dos fenômenos da natureza, do desconhecido, do inexplicável. Desde as sociedades humanas primitivas até aos nossos dias, acompanhando a evolução do conhecimento científico, a ideia de mito foi perdendo o seu valor original e passou a ser usado para designar uma história falsa, fantasiosa, inventada, irreal. De alguma forma, o mito perdeu para a História o seu significado de relato verdadeiro, credível e real. Hoje, mito e História são vulgarmente dois conceitos antagônicos.

O mito teve origem na Grécia antiga sendo sinônimo de história exemplar, de uma narrativa que trás ensinamentos, e leva aprendizados, podendo ser também algo verídico que aconteceu. Mas, a veracidade do mito perdeu a credibilidade com a dominação dos romanos sobre os gregos, eles não acreditavam nesses mitos e assim o mito acabou por se tornar sinônimo de mentira.

O fato de o homem moderno ser uma geração marcada pela não crença do mito pode ser atribuído por estar numa sociedade onde a religião é optativa e o estado perante a lei é laico, diante essa situação percebe-se um afastamento das religiões e consequentemente dos mitos que são a fundamentação do sagrado.

Por outro lado, têm-se as Lendas que são mais propagadas pela forma oral possuindo a sistematização e a ordenação da realidade dessa maneira possuindo mais garantia.

As lendas são episódio heroico ou sentimental com elemento maravilhoso ou sobre-humano, transmitido e conservado na tradição oral e popular localizável no espaço e no tempo. De origem letrada, lenda, legenda, 'legere' possui características de fixação geográfica e pequena deformação e conserva-se as quatros características do conto popular: antiguidade, persistência, anonimato e oralidade. É muito confundido com o mito, dele se distância pela função e confronto. $\mathrm{O}$ mito pode ser um sistema de lendas, gravitando ao redor de um tema central com área geográfica mais ampla e sem exigências de fixação no tempo e no espaço (CASCUDO,1976, p. 348).

Ao combinar a fantasia e o elemento real a lenda tem o objetivo de caracterizar os arquétipos e a temática cultura, sendo assim como o mito uma narrativa que envolve o místico com noção de sagrado podendo não somente, mas também envolver o poder do religioso.

A lenda tem origem em uma determinada região que por ser repassada através da oralidade pode sofrer algumas modificações, mas mantém a explicação de um fenômeno da natureza, da origem do homem ou de costumes de um povo, envolvendo sempre o fato ou façanhas.

Tanto o mito quanto a lenda fazem parte da tradição oral, ambos têm inestimável valor 
cultural e literário. No entanto, o conteúdo da lenda trata-se de elementos de ficção que podem estar baseados em algum acontecimento histórico, mas que com o passar dos anos foram se enriquecendo com características de fantasia, por isso possui sistematização de realidade.

Já o mito é uma narração que protagoniza personagens sobrenaturais e heroicos, mas que ao invés de narrar acontecimentos históricos procuram explicar a origem do mundo, os fenômenos naturais ou determinados aspectos religiosos vinculados a essa comunidade ou civilização.

\section{ANÁLISES DOS RELATOS}

As narrativas a seguir foram colhidas no Ilê Omo Osún, estas servem tanto para a transmissão de conhecimentos e segredos quanto para a aprendizagem dos textos ritualísticos.

Como se poderá notar nas análises das narrativas yorubás, a ausência da tradição escrita não impede que a oralidade crie a literatura em uma sociedade e ainda repassá-la por várias gerações. O Itan citado acima por todos os seis colaboradores chama atenção ao perceberse que alguns se referem a ele como lenda e outros se referem como mito. Esse é um grande equívoco na cabeça das pessoas que fazem parte da religião do Candomblé e também das pessoas que mesmo não pertencendo à religião, conhecem e estudam o Itan.

Para ajudar a identificar se essas narrativas são mitos ou lendas o estudo do Itan recolhido no Ilê Omo Osún serve de base para o estudo das características de mito. Vê-se que explicam a origem do mundo como no Itan "A criação do mundo" narrado na Entrevista 01, com o Babalorixá José d'Oxum, pode-se perceber que envolve acontecimentos relativos a criação dos cosmos, são "mitos cosmogônicos", estes narram a origem e evolução da Terra:

"A criação do mundo"

Deus o criador do universo, na cultura Yorubá chamado de Olodumaré, enviou para o universo o orixá da criação, Oxalá, logo ele criou o mundo, porém faltava vida, percebendo que precisava de água para gerar vida, Olodumaré pediu a Yemanjá e a Oxum que fossem á Terra e resolvessem isso. Oxum com sua feminilidade criou rios e cachoeiras com água doce e Yemanjá cobriu parte do planeta com a água salgada criando os oceanos. Á Omolu, Olodumaré encarregou que criasse a terra, solos firmes e férteis e a Nanã que criasse o barro, desse barro seria feito o homem, mas somente o próprio Olodumaré o daria vida. Ao ver que a terra precisava de alimentos, animais e vegetais, Olodumaré enviou Oxóssi o rei da floresta que criou a fauna e a flora, sobre as ervas e plantas medicinais enviou Ossain. Nas matas fechadas que Oxóssi criou precisaram ser abertos caminhos para facilitar a transição no mundo, então Ogum veio com suas ferramentas de ferro forjadas por ele mesmo e abriu caminhos. A Terra precisava de chuva então o Deus criador pediu que Ewá evaporasse as águas dos rios e oceanos formando-as em nuvens e seu irmão gêmeo Oxumaré desfizesse essas nuvens transformando-as em chuvas, desceram também Oyá e Xangô, ela com o raio e os ventos e ele com o trovão e as pedras, eles trouxeram o fogo ao mundo. Vendo que o mundo precisava de humanos Exú ficou responsável pela sexualidade entre eles e para que assim se reproduzissem. Foi assim que Olodumaré criou o mundo, com a ajuda dos orixás e os deixou que ficassem por aqui ajudando seus filhos (os humanos) e os auxiliando para que sempre possam fazer o bem (Entrevista 01 - Babalorixá José d'Oxum)

Já na Entrevista 02, Maria d' Oxum nos diz que Exú deve ser primeiro a ser agradado, assemelha-se as características do "mito cultural" pois procuram dar uma explicação do início de um costume. Neste caso, o Itan explica o motivo pelo qual o orixá Exú deve ser o primeiro a receber oferendas dentro do culto do Candomblé. 
"Exú é o primeiro que deve ser agradado"

Os orixás reuniram-se para discutir os últimos acontecidos na Terra e cada um levou um prato com sua comida preferida para cearem juntos. Foi organizado um grande banquete, e a maioria estava lá, só faltou Exú que havia se atrasado. Os orixás não quiseram esperar e se serviram, porém a comida havia acabado e quando Exú chegou não haviam deixado nada para que ele matasse a fome. Exú ficou irado de raiva e foi se queixar com Olodumaré que determinou que a partir daquele dia Exú seria o primeiro orixá a ser servido, não importava qual fosse a ocasião, os outros só comeriam depois dele (Entrevista 02-Maria d' Oxum)

\section{A narrativa da Entrevista 03, Pedro d'Oxúm relata a rivalidade entre Oxum e Obá:}

"A maldade de Oxum contra Obá"

Xangô era o rei de Oyó, guerreiro, justiceiro, determinado, ele tinha três esposas, eram elas: Obá, Oxum e Oyá. Obá, senhora dos redemoinhos era uma guerreira muito dedicada ás suas batalhas, possuía um porte masculinizado e não tinha tempo para a feminilidade, nem cuidar da casa e do esposo. Já Oxum, senhora das águas doces, não era guerreira, era mais vaidosa e feminina, tinha tempo de se cuidar e gostava de se olhar no espelho, se perfumar, cuidar da beleza e também cuidava da casa, gostava de agradar seu esposo quando ele chegasse das batalhas. Oyá é a senhora dos ventos e raios, estava sempre ao lado do esposo realmente, o acompanhava em todas as suas viagens e batalhas, também era muito bela. Certo dia Obá se sentindo desprezada pelo marido decidiu conversar com Oxum que estava usando um belo turbante dourado cobrindo as orelhas, muito bonito por sinal. Admirando a beleza de Oxum, obá perguntou: - Oxum, o que você faz para que Xangô te dê tanta atenção? Oxum muito treteira se aproveitando da ingenuidade de Obá, estava com uma gamela em mãos, apenas respondeu: E muito simples Obá, eu cortei uma orelha e coloquei no amalá (uma das comidas preferidas de Xangô). Dando uma risada Oxum saiu. Obá ficou pensativa e decidiu fazer como Oxum disse que fez, então cortou a própria orelha e colocou-a sobre a comida que cozinhou pra Xangô. Xangô havia acabado de chegar de uma de suas batalhas, estava cansado e faminto, e Obá levou o amalá que havia preparado. Quando Xangô se deparou com aquele amalá com uma orelha humana sangrando no meio de sua comida, ficou muito furioso e deu um grito enorme. Ao perguntar a Obá o que havia acontecido ela contou que somente agora havia percebido que fora enganada por Oxúm que mentiu sobre ter cortado sua orelha. Xangô quis matar as duas, mas elas fugiram em forma de rio. Assim surgiram dois grandes rios da África, Oxúm é a dona das cachoeiras e águas tranquilas já Obá é dona da correnteza e da foz do rio. Até hoje Obá e Oxum se odeiam. Assim o rei Xangô ficou com sua rainha Oyá que era mesmo quem estava mais presente com ele (Entrevista 03 - Pedro d'Oxúm)

Da mesma forma que se observou na entrevista anterior, a Entrevista 04, de Roberto d'Oxúm, lê-se que a curiosidade de Oyá também narra um "mito natural", pois retrata os poderes que tem a senhora dos ventos, Oyá.

"A curiosidade de Oyá"

Ossain havia recebido de Olodumaré o segredo das ervas, assim elas vieram a Terra, no intuito de ajudar o homem e curar doenças dentre outras funções. Estas eram de propriedade de Ossain e não dava a ninguém. Até o dia em que Xangô se queixou a sua mulher Oyá, senhora dos ventos, que somente Ossain sabia dos segredos das folhas. Isso despertou a curiosidade de Oyá, que foi procurar Ossain, ao encontra-lo viu uma cabaça pendurada numa árvore, nessa cabaça ele guardava o seu segredo. Querendo descobrir o que havia dentro da cabaça. Oyá criou um vento muito violento que acabou derrubando a cabaça e o segredo acabou se espalhado em forma de folhas. Cada orixá pegou uma folha acreditando possuir parte do segredo, porém apesar das folhas espalhadas apenas Ossain sabia como usá-las e assim os segredos das ervas continuaram pertencendo a Ossain (Entrevista 04 - Roberto d'Oxúm)

$\mathrm{Na}$ narrativa da Entrevista 05, Carlos d'Ogun fala do arrependimento de Ogun possui características do Mito etimológico, este retrata as questões morais sendo que nesse Itan 
Ogun num ato de raiva se descontrola matando algumas pessoas e depois usando de bom senso e moral acaba se arrependendo, este Itan também é um "mito teológico", pois explica como Ogum se tornou uma divindade sagrada.

"O arrependimento de Ogun"

Ogun é orixá guerreiro, nunca teve morada certa, é o senhor que abre caminhos mundo a fora, ele era o pai do rei de Irê. Certo dia foi visitar seu filho depois de muito tempo longe. No dia que chegou esperava uma festa quando o vissem como era de costume ser bem recebido, mas quando chegou ninguém o reconheceu e também não falaram com ele e não respondiam suas perguntas. O que Ogun não sabia era que naquele dia estava sendo celebrado um voto de silêncio, aonde as pessoas não podiam falar em hipótese alguma. Ogun não sabia de nada e ser ignorado atiçou sua ira que saiu quebrando tudo com sua espada e não se contendo decapitou a cabeça de algumas pessoas que se aproximaram dele. Até que seu filho apareceu para explicar sobre o voto de silêncio que acontecia naquele dia. Arrependido Ogun lamentou sua atitude nervosa e apontou sua espada para o chão pronunciando algumas palavras pedindo a Olodumaré que o tornasse orixá, e assim foi concebido. (Entrevista 05 - Carlos d’Ogun)

Por fim, na Entrevista 06, Paulo d'Logun Edé narra sobre Logun Edé, menino teimoso, que possui características de lendas do tipo "pessoal" e "local". Pessoal por tratar Oyá como heroína e Obá como vilã, e características locais por tratar-se de estar vinculada ao encontro de dois rios de uma localidade africana.

\begin{abstract}
"Logun Edé, menino teimoso"
Logun Edé é filho de Oxum e de Oxóssi, o mesmo vivia num acordo feito com por sua mãe e por seu pai, vivia seis meses com Oxum nas águas dos rios e seis meses com Oxóssi nas matas. O menino nadava feito um peixinho assim como a mãe, Oxum sempre o supervisionava e o orientava para não ir para a parte mais turbulenta do rio, pois lá era fundo e perigoso e pertencia a sua inimiga, Obá. Como Oxum já havia usado de suas artimanhas maquiavélicas para prejudicar Obá tinha medo que ela quisesse se vingar no menino. Logun era uma criança teimosa e não ouviu nada do que disse sua mãe, foi nadando, nadando e quando deu por si já estava num local onde o curso das águas de Oxum acaba; estavam na foz do rio, onde ele deságua no rio de Obá sendo afogado por ela. Ao ouvir os gritos Oxum ficou desesperada, mas não podia fazer nada porque ali não eram águas do seu domínio, então ela clamou para que Olodumare salvasse o seu filho. Olodumaré então pede a Oyá, a senhora dos ventos para salvar o menino, ela logo cria um tornado na água que arremessa Logun Edé para fora do rio. Oyá ficou encarregada de adotar o menino e terminar de criá-lo (Entrevista 06 - Paulo d'Logun Edé)
\end{abstract}

O mito apesar de não ter lógica alguma são narrativas que procuram dar razão aos fatos, justificando a origem do mundo, ainda que não expliquem os fatos corretamente para a ciência, eles mostram uma realidade paralela que não pode ser examinada e comprovada, e por esse motivo é visto como algo fantasioso, uma invenção, mentiras criadas pelos povos antigos.

A lenda apesar de fazer uso da fantasia, misturam fatos históricos combinando a fantasia e o elemento real a lenda tem o objetivo de caracterizar os arquétipos e a temática cultura. Então o Itan pode ser considerado mito por uns e lendas por outros, pois sua literatura nos dá características de mitos e lendas, porém ela não pode ser os dois ao mesmo tempo, isso vai depender da crença ou não particular de cada um que tem acesso ao Itan.

Algumas pessoas acreditam que o Itan seja os mitos do panteão africano, veem os orixás como Deuses da religião do Candomblé, porém são pessoas que não fazem parte da religião, e não acreditam no Itan como algo que já aconteceu, neste caso o Itan é mito, pois não há ordenação com a realidade. 
Por outro lado há as pessoas que fazem parte do Candomblé, e acreditam que o Itan seja algo real que aconteceu há muito tempo atrás, e que os orixás eram nossos ancestrais, homens e mulheres que viveram na Terra e foram divinizados, neste caso o Itan é uma lenda, pois apesar de combinar a fantasia e o elemento real, a lenda tem o objetivo de caracterizar os arquétipos exatamente o que acontece com o Itan quando individualiza cada pessoa como filho de um orixá.

\section{CONSIDERAÇÕES FINAIS}

Neste artigo, discutiu-se o conceito de mito e lendas, no sentido de fazer uma definição sobre a maneira de analisar de cada um que tem acesso ao Itan, de acordo com a crença particular.

A relação entre o Itan e a literatura é evidente e não deixa dúvidas de que este se estrutura sobre as características dos elementos da narrativa. O Itan está marcado pela necessidade que os terreiros têm do uso da tradição oral como parte integrante de seu universo, dos rituais e da própria identidade.

O Itan é um objeto tem seu surgimento através da oralidade, descrevendo os Orixás como personagens fundamentais pelo desempenho do enredo e em suas ricas características que possuem relações tanto com o mito quanto com a lenda, de maneira que a visão de mundo de quem o lê é determinante para sua classificação enquanto mito ou lenda.

Espera-se que este trabalho venha a contribuir para o discernimento do Itan, de modo que através dessa literatura sejam resgatadas a beleza, a nobreza e os ensinamentos dos Orixás, da cultura africana no Brasil. Por fim, espera-se que isso ajude na luta contra o preconceito e estigmatização de que os orixás e suas narrativas façam parte de uma religião do mal.

\section{REFERÊNCIAS}

ARAÚJO, Carlos. ABC dos orixás. São Paulo: Círculo do livro, 1993.

ARINOS, Afonso. Lendas e tradições brasileiras. Rio de Janeiro: Briguiet e Cia, 1937. BARBOSA JR., A. O essencial do Candomblé. São Paulo: Universo dos livros, 2011. CASCUDO, Luís da Câmara. Dicionário do folclore brasileiro. Brasília: J. Olympio, INL, 1976.

ELIADE, Mircea. Mito e realidade. São Paulo. Perspectiva. 1972.

FONTES, Vítor José de Oliveira. O potencial didático dos mitos e das lendas na educação histórica. Porto, 2013.

MARCUSCHI, Luiz Antônio. Fala e escrita. Belo Horizonte: Autêntica, 2007.

PÓVOAS, Ruy do Carmo. Itan dos mais-velhos: contos. Ilhéus: Editus, 2004.

VANSINA, J. A tradição oral e sua metodologia. Disponível em «http:/ /afrologia.blogspot.com.br/2008/03/tradio-oral-e-sua-metodologia.html». Acesso em 30 out. 2016.

VERGER, Pierre Fatumbi. Orixás, deuses iorubas na África e novo mundo. Salvador: Corrupio, 1997. 